\title{
Macrophage Migration Inhibitory Factor Expression in Male and Female Ethanol-Fed Rats
}

\author{
AMIN A. NANJI, ${ }^{1}$ GEORGE K.K. LAU, ${ }^{2}$ GEORGE L. TIPOE,${ }^{3}$ SIU TSAN YUEN, ${ }^{1}$ YONG X. CHEN, ${ }^{2}$ \\ PETER THOMAS, ${ }^{4}$ and HUI Y. LAN ${ }^{2}$
}

\begin{abstract}
Macrophage migration inhibitory factory (MIF) regulates macrophage accumulation at sites of injury and can promote the inflammatory response. We studied MIF expression in the intragastric feeding rat model for alcoholic liver injury. Male and age-matched female rats were fed ethanol or dextrose with fish oil. Two groups of male rats were fed medium-chain triglycerides with ethanol or dextrose. Analysis of liver histopathology, lipid peroxidation, endotoxin, mRNA, and immunohistochemistry for MIF, tumor necrosis factor- $\alpha$ (TNF- $\alpha$ ) and interferon- $\gamma($ IFN- $\gamma)$ were carried out. Male and female rats fed fish oil and ethanol showed necroinflammatory liver injury and had the highest expression of MIF, TNF- $\alpha$, and IFN- $\gamma$ in the liver. Decreased levels of MIF protein were seen in rats with higher endotoxin levels, suggesting that preformed MIF is released into the circulation. MIF is an important mediator of the inflammatory response in alcoholic liver disease and a potential therapeutic target.
\end{abstract}

\section{INTRODUCTION}

A LCOHOLIC LIVER INJURY is a complex process involving several injury mechanisms and multiple cellular targets. ${ }^{(1)}$ Several studies indicate that endotoxin and oxidative stress are important pathogenic mechanisms in alcohol-induced liver injury. ${ }^{(2-5)}$ It is well known that endotoxin is hepatotoxic and that concentrations of endotoxin are increased in alcoholic liver disease in experimental animals and humans. ${ }^{(2,3,6)}$ One pathway by which endotoxemia and oxidative stress can cause liver injury is through activation of nuclear factor $\kappa \mathrm{B}(\mathrm{NF}-\kappa \mathrm{B})$, which upregulates the production of proinflammatory cytokines, such as tumor necrosis factor- $\alpha$ (TNF- $\alpha$ ) and interferon- $\gamma$ (IFN$\gamma) .^{(7-9)}$

A key molecule that upregulates TNF- $\alpha$ and IFN- $\gamma$ and promotes the inflammatory response is macrophage migration inhibitory factor (MIF). ${ }^{(10,11)}$ MIF was originally described as a lymphokine derived from activated $\mathrm{T}$ cells that inhibited the migration of macrophages. ${ }^{(12)}$ Subsequently, it was shown that MIF is expressed in a variety of cells and tissues, including the liver. ${ }^{(10)}$ Based on the information available about factors that stimulate expression of MIF, we hypothesized that MIF would be induced in experimental alcoholic liver disease (ALD).

To evaluate the relationship between pathologic liver injury and expression of MIF, we used the rat intragastric feeding model for ALD. ${ }^{(13,14)}$ We and others have shown an inverse relationship between the saturation of lipids in the diet and the severity of alcohol-induced liver injury. ${ }^{(15,16)}$ Rats fed ethanol and a diet enriched in saturated fatty acids are protected from liver injury, ${ }^{(16)}$ whereas diets enriched in polyunsaturated fatty acids promote alcoholic liver injury. ${ }^{(15)} \mathrm{We}$ and others have also shown that female rats are more susceptible to alcoholic liver injury than male rats and show more severe necrosis and inflammation. ${ }^{(17)}$ Thus, the intragastric feeding model using male and female rats is useful to elucidate the relationship between pathologic changes in liver and proinflammatory mediators, such as MIF.

Our results show that necrosis and inflammation in ALD are associated with increased expression of MIF. The Kupffer cell and other mononuclear cells are the most likely source of MIF, although endothelial cells and hepatocytes also make a contribution. The upregulation of IFN- $\gamma$ and TNF- $\alpha$ in association

${ }^{1}$ Department of Pathology and Center for the Study of Liver Diseases and ${ }^{2}$ Department of Medicine, The University of Hong Kong and Queen Mary Hospital, Hong Kong.

${ }^{3}$ Department of Anatomy, The University of Hong Kong, Hong Kong.

${ }^{4}$ Department of Surgery, Boston University School of Medicine, Boston, MA 02119. 
with MIF also contributes to the inflammatory changes in alcoholic liver injury.

\section{MATERIALS AND METHODS}

\section{Animals}

Male Wistar rats weighing between 275 and $300 \mathrm{~g}$ were fed a liquid diet by continuous infusion through permanently implanted gastric tubes as described previously. ${ }^{(13,14)}$ The rats were given their total nutrient intake by intragastric infusion. The percentage of calories derived from fat was $35 \%$ of total calories. Vitamins and minerals were given as described previously. ${ }^{(14)}$ The amount of ethanol was modified to maintain high levels of blood ethanol $(150-300 \mathrm{mg} / \mathrm{dl})$ throughout the day. The amount of ethanol was initially 10 $\mathrm{g} / \mathrm{kg} /$ day and was increased to $16 \mathrm{~g} / \mathrm{kg} /$ day as tolerance developed. Each ethanol-fed rat had at least two measurements of blood alcohol.

In the first set of experiments, six groups of rats ( 5 rats per group) fed different dietary fats with ethanol or dextrose were studied. These groups were male rats fed medium-chain triglycerides plus dextrose (MCTD) or ethanol (MCTE) and fish oil plus dextrose (FD) or ethanol (FE). In addition, age-matched female rats were fed fish oil and dextrose (FFD) or ethanol (FFE). All control animals were pair-fed the same diet as ethanol-fed rats except that ethanol was isocalorically replaced by dextrose. All diets were prepared fresh daily. All animals were killed after 1 month of treatment with the experimental diets. When the animals were killed, a sample of liver was obtained for histopathologicanalysis, and the rest of the liver was rapidly excised, washed with ice-cold $1.15 \%(\mathrm{w} / \mathrm{v}) \mathrm{KCl}$, and cut into small pieces. The liver specimens were transferred to plastic vials and placed in liquid nitrogen, and the vials were stored at $-80^{\circ} \mathrm{C}$. All animals received humane care in compliance with the National Institutes of Health criteria for care of laboratory animals.

In the second set of experiments, which were designed to evaluate the cellular source of MIF, IFN- $\gamma$, and TNF- $\alpha$ mRNA, six groups of animals were evaluated (MCTD, MCTE, FD, FE, FFD, and FFE). All animals were killed after treatment with the experimental diets for 1 month.

\section{Isolation of hepatocytes, Kupffer cells, and endothelial cells}

Cells were isolated from anesthetized rats using procedures described previously ${ }^{(18)}$ and isolation buffers described by Seglen. ${ }^{(19)}$ Hepatocytes, Kupffer cells, and endothelial cells were isolated as previously described.(20) Briefly, after intravenous administration of sodium heparin (100 U), the livers were exsanguinated in situ by portal vein perfusion with $\mathrm{Ca}^{2+}$ free buffer. Livers were excised, minced, and subsequently incubated in $0.05 \%$ collagenase in buffer. The different cell types were identified by morphology and immunohistochemical markers that included peroxidase, acid phosphatase, $\alpha_{1}$-antichymotrypsin, ED1, and cytokeratins.(21) Endothelial cells were the nonadherent cells from the Kupffer cell preparation and were placed onto type 1 collagen-coated dishes. The cells were stored at $-70^{\circ} \mathrm{C}$.

\section{Histopathologic analysis}

A small sample of the liver was obtained and formalin-fixed when the rats were killed. H \& E stain was used for light microscopy. The severity of liver pathology was assessed as follows: steatosis (the percentage of liver cells containing fat) was scored $1+$ with $<25 \%$ of the cells containing fat, $2+$ with $26 \%-50 \%$ of the cells containing fat, $3+$ with $51 \%-75 \%$ of the cells containing fat, and $4+$ with $>75 \%$ of the cells containing fat. Necrosis was quantified as the number of necrotic foci per square millimeter, and inflammation was scored as the number of inflammatory cells per square millimeter. At least three different sections were examined per sample of liver. The pathology was assessed blindly without knowledge of the experimental groups.

\section{Measurement of blood alcohol}

Blood was collected from the tail vein, and ethanol concentration was measured using an alcohol dehydrogenase kit from Sigma Chemical Co. (St. Louis, MO).

\section{Measurement of conjugated dienes}

Conjugated dienes in the total lipid extracted from liver homogenates were determined as described previously. ${ }^{(20)}$

Table 1. Pathologic Changes in Experimental Groups

\begin{tabular}{lccc}
\hline Treatment group & $\begin{array}{c}\text { Fatty liver } \\
(0-4)\end{array}$ & $\begin{array}{c}\text { Necrosis } \\
(\text { foci/mm }\end{array}$ & $\begin{array}{c}\text { Inflammation } \\
(\text { cells/mm }\end{array}$ \\
\hline Medium-chain triglycerides + dextrose (MCTD) & 0.0 & 0.0 & 0.0 \\
Medium-chain triglycerides + ethanol (MCTE) & 0.0 & $0.07 \pm 0.04$ & 0.0 \\
Fish oil + dextrose (FD) & 0.0 & $0.08 \pm 0.04$ & $0.6 \pm 0.02$ \\
Fish oil + ethanol (FE) & $4.0 \pm 0 . \mathrm{m}^{*}$ & $1.1 \pm 0.4^{*}$ & $21.2 \pm 7.3^{*}$ \\
Female fish oil + dextrose (FFD) & $2.0 \pm 0.4^{*}, * *$ & $0.4 \pm 0.2^{* * * *}$ & $8.2 \pm 2.3^{* * * *}$ \\
Female fish oil + ethanol (FFE) & $4.0 \pm 0.0^{*}$ & $1.4 \pm 0.4^{*}$ & $54.5 \pm 11.8^{* * * * *}$ \\
\hline
\end{tabular}

$* p<0.01$ vs. MCTD, MCTE, FD.

$* * p<0.05$ vs. FE, FFE.

$* * * p<0.05$ vs. FE. 


\section{Measurement of plasma endotoxin}

Endotoxin in plasma was measured as described previously $^{(3)}$ using the appropriate precautionary measures. ${ }^{(22)}$

Analysis of mRNA for MIF, TNF- $\alpha, I F N-\gamma$, and $\beta$-actin by reverse transcriptase-polymerase chain reaction ( $R T-P C R)$

To examine the expression of MIF, TNF- $\alpha$, IFN- $\gamma$, and $\beta$ actin in liver tissue and cells, total RNA was isolated according to the guanidinium isothiocyanate method. ${ }^{(23)}$ The integrity of RNA was assessed by agarose gel electrophoresis and ethidium bromide staining. RT-PCR was performed essentially as previously described. ${ }^{(20,24)}$ The sequences of primer pairs, 5' and $3^{\prime}$, and predicted sizes of the amplified PCR fragments for MIF, TNF- $\alpha$, IFN- $\gamma$, and $\beta$-actin have been reported previously. ${ }^{20,25,26} \mathrm{PCR}$ products and molecular weight markers were subjected to electrophoresis on $1 \%$ agarose gels and visualized by means of ethidium bromide staining. The gels were analyzed by laser scanning densitometry using a Molecular Dynamics Densitometer and Image Quant software (Molecular Dynamics, Sunnyvale, CA). Each experiment included a negative control (sample RNA that had not been subjected to RT). Varying the number of PCR cycles did not change the relative differences between the samples, indicating that the PCR conditions were not within the plateau phase of amplification. All amplification reactions of one experiment were performed in parallel in the same heating block to ensure compatible conditions.

\section{In situ hybridization and immunohistochemical} analysis of MIF

In situ hybridization was performed on paraffin sections of formalin-fixed tissue with MIF antisense or sense cRNA probes as previously described. ${ }^{(27,28)}$ MIF protein expression was determined by immunostaining with the antimouse MIF monoclonal antibody $(\mathrm{mAb})$. The specificity of the antisense probe and anti-MIF antibody was confirmed as described previously. ${ }^{(27,28)}$ In addition, some sections were also stained with the ED1 mAb using the peroxidase-antiperoxidase (PAP) method and counterstained with periodic acid-Schiff for immunohistochemical analysis of MIF. The sections were scored as previously described ${ }^{(10)}$ : 0 , negative; 1,20 positively staining cells per high-power field (HPF); $2+, 20-40$ positive cells per HPF; and $3+,>40$ cells per HPF.

\section{Statistical analysis}

All data are expressed as means \pm SD unless otherwise indicated. Statistical significance was evaluated using the unpaired Student's $t$-test for comparison between two means. Differences between more than 2 groups were analyzed using analysis of variance (ANOVA). Statistical significance was set at $p<0.05$.

\section{RESULTS}

Some of the results, such as histopathologic findings, have been described previously for some of the animals included in other studies. ${ }^{(20,24)}$ There was no difference in weight gain

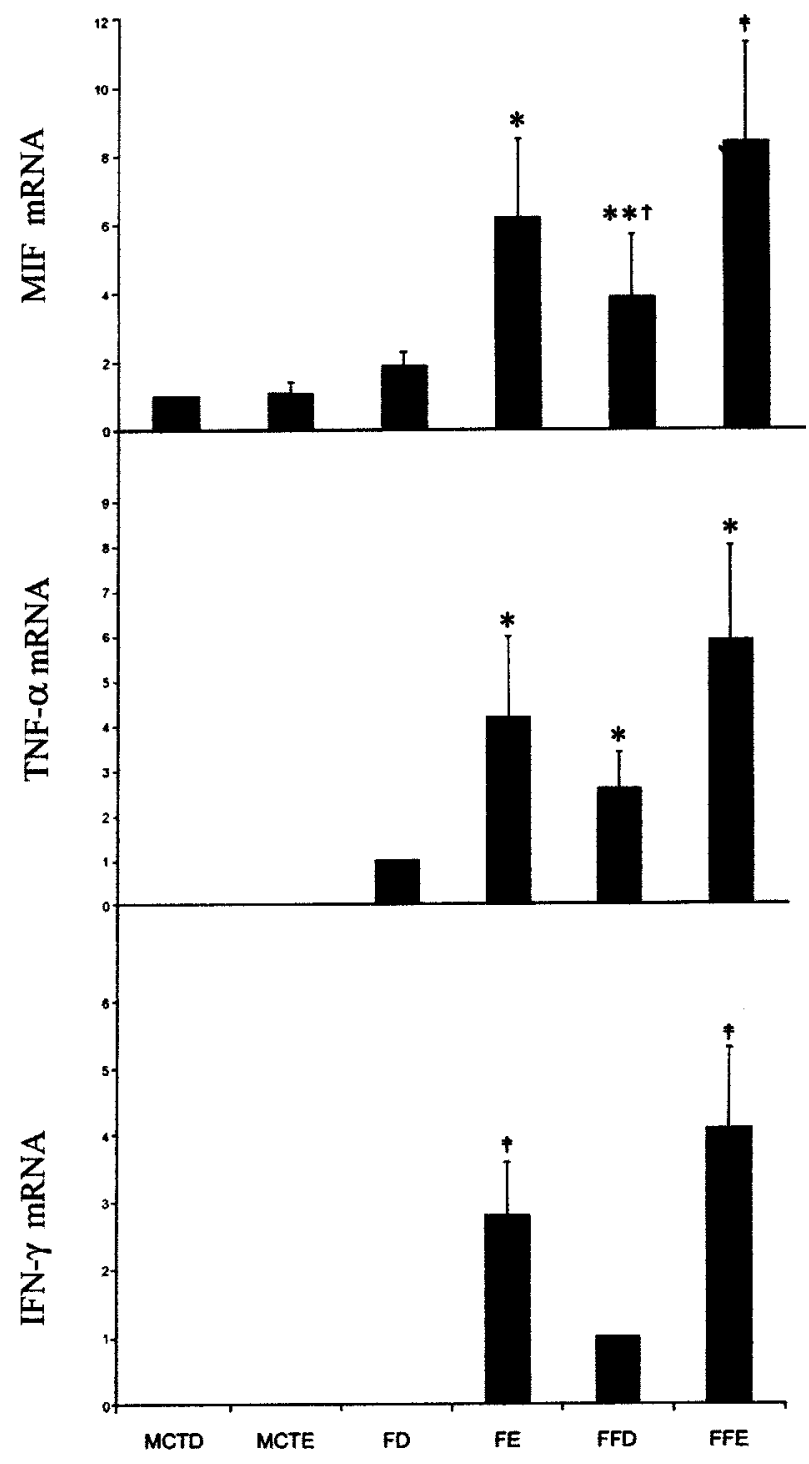

FIG. 1. Quantitation of MIF, TNF- $\alpha$, and IFN- $\gamma$ expression in the various experimental groups. MIF expression was detectable in the MCTD, MCTE, and FD groups. MIF mRNA was significantly increased in FE rats compared with MCTD, MCTE, and FD groups $(p<0.01)$. Female rats fed fish oil and dextrose had significantly higher levels of MIF mRNA compared with MCTD and MCTE $(p<0.02)$ and FD groups $(p<$ 0.05). Female fish oil plus ethanol-fed rats had higher MIF mRNA levels compared with MCTD, MCTE, FE, and FFD groups $(p<0.01)$. TNF- $\alpha$ mRNA was not detected in MCTD and MCTE groups and was increased in FE, FD, and FFD groups in comparison to other groups $(p<0.01)$. IFN- $\gamma$ was not detected in MCTD, MCTE, and FD groups. Levels of IFN$\gamma$ were highest in FE and FFE groups. All mRNA levels were quantified using $\beta$-actin as standard. ${ }^{*} p<0.01$ vs. MCTD, MCTE, FD groups; $* * p<0.02$ vs. MCTD and MCTE groups; $\dagger p<0.05$ vs. FD; $\ddagger p<0.05$ vs. FFD and $p<0.01$ vs. MCTD, MCTE, FD. MCT, medium-chain triglycerides; F, fish oil; FF, female fish oil; D, dextrose; E, ethanol. 
Table 2. Levels of Plasma Endotoxin and Conjugated Dienes

$\left(\mathrm{A}_{232}\right)$ in Liver in Experimental Groups

\begin{tabular}{lcc}
\hline Treatment group & $\begin{array}{c}\text { Endotoxin } \\
(\mathrm{pg} / \mathrm{ml})\end{array}$ & $A_{232}$ \\
\hline Medium-chain triglycerides + dextrose (MCTD) & $5 \pm 3$ & $0.06 \pm 0.02$ \\
Medium-chain triglycerides + ethanol (MCTE) & $12 \pm 5$ & $0.12 \pm 0.05$ \\
Fish oil + dextrose (FD) & $7 \pm 2$ & $0.39 \pm 1.16^{* * *}$ \\
Fish oil + ethanol (FE) & $62 \pm 11^{*}$ & $0.67 \pm 0.18^{*}$ \\
Female fish oil + dextrose (FFD) & $22 \pm 4^{* * *}$ & $0.44 \pm 0.19^{* * *}$ \\
Female fish oil + ethanol (FFE) & $84 \pm 14^{* * * * *}$ & $0.86 \pm 0.22^{*, * * * *}$ \\
\hline
\end{tabular}

$* p<0.01$ vs. MCTD, MCTE, FD.

$* * p<0.01$ vs. FD, FFE.

$* * * p<0.01$ vs. MCTD, MCTE

$* * * * p<0.01$ vs. FFD.

among the different experimental groups (data not shown). No significant difference in blood alcohol levels was found among the ethanol-fed groups. The blood alcohol levels in the ethanol-fed groups were as follows: MCTE $232 \pm 38 \mathrm{mg} / \mathrm{dl}$, FE $229 \pm 31 \mathrm{mg} / \mathrm{dl}$, and FFE $242 \pm 24 \mathrm{mg} / \mathrm{dl}$. The amount of alcohol administered $(\mathrm{g} / \mathrm{kg})$ was not different in the different groups.

\section{Histopathology}

The most severe pathology was seen in the male and female ethanol-fed rats (Table 1). In particular, the degree of necrosis and inflammation was much more severe in female rats. The male dextrose-fed rats showed no pathologic signs. In contrast, the female dextrose-fed rats had fatty liver, necrosis, and inflammation.

\section{Enhanced expression of MIF and TNF- $\alpha$ and} correlates with inflammatory changes, endotoxemia, and lipid peroxidation

We examined liver tissue for MIF by RT-PCR. MIF mRNA normalized using $\beta$-actin was detected in all experimental groups; However, the groups showing necrosis and inflammation and having increased levels of lipid peroxidation and endotoxin had the highest levels of MIF mRNA (Fig. 1 and Table
2). Because MIF upregulates TNF- $\alpha$ and IFN- $\gamma$, we also evaluated mRNA levels of these two cytokines in liver. Our results show that upregulation of TNF- $\alpha$ and IFN- $\gamma$ mRNA is similar to that seen with MIF in the different experimental groups (Fig. 1).

\section{Cellular origin of MIF $m R N A$}

We next attempted to determine the cell type in liver responsible for increased MIF mRNA. Hepatocytes, Kupffer cells, and endothelial cells were isolated from the rats fed the different experimental diets. MIF mRNA was detected in all three cell types in all the groups. The highest levels of MIF mRNA were seen in all cell types in the fish oil-ethanol-fed male and female rats (Table 3). Because the isolation procedure yields Kupffer and endothelial cells with $85 \%-90 \%$ purity, we cannot exclude the possibility that detectable levels of MIF mRNA in endothelial cells and hepatocytes in the rats exhibiting liver injury reflected contamination by Kupffer cells.

\section{Increased MIF mRNA is associated with increased $m R N A$ levels of TNF- $\alpha$ and IFN- $\gamma$}

Based on experimental evidence that MIF production can upregulate TNF- $\alpha$ and IFN- $\gamma$ synthesis and our observation that TNF- $\alpha$ and IFN- $\gamma$ are upregulated in conjunction with

Table 3. Mif mRna Levels in Various Cell Types in Experimental Groups

\begin{tabular}{lccc}
\hline & & Cell type \\
\cline { 2 - 4 } Treatment group & Kupffer & Endothelial & Hepatocyte \\
\hline Medium-chain triglycerides + dextrose (MCTD) & 1.0 & 1.0 & 1.0 \\
Medium-chain triglycerides + ethanol (MCTE) & $0.9 \pm 0.3$ & $0.8 \pm 0.4$ & $1.3 \pm 0.3$ \\
Fish oil + dextrose (FD) & $1.4 \pm 0.5$ & $1.0 \pm 0.4$ & $1.8 \pm 0.8$ \\
Fish oil + ethanol (FE) & $7.0 \pm 2.6^{*}$ & $6.4 \pm 1.9 *$ & $3.2 \pm 1.1^{* * *}$ \\
Female fish oil + dextrose (FFD) & $3.2 \pm 1.2^{* *}$ & $3.0 \pm 0.9^{* *}$ & $3.6 \pm 0.7 * * *$ \\
Female fish oil + ethanol (FFE) & $8.6 \pm 3.0^{*}$ & $7.6 \pm 2.1^{*}$ & $4.2 \pm 2.0^{* * *}$ \\
\hline
\end{tabular}

$* p<0.01$ vs. MCTD, MCTE, FD.

$* * p<0.05$ vs. FD, FFE.

$* * * p<0.05$ vs. MCTD, MCTE. 
Table 4. Expression of TNF- $\alpha$ and IFN- $\gamma$ mRNA in KupfFer and Endothelial Cells in Experimental Groups ${ }^{a}$

\begin{tabular}{|c|c|c|c|c|}
\hline \multirow[b]{2}{*}{ Treatment group } & \multicolumn{2}{|c|}{ Kupffer cells } & \multicolumn{2}{|c|}{ Endothelial cells } \\
\hline & $T N F-\alpha$ & $I F N-\gamma$ & $T N F-\alpha$ & $I F N-\gamma$ \\
\hline Medium-chain triglycerides + dextrose (MCTD) & 0 & 0 & 0 & 0 \\
\hline Medium-chain triglycerides + ethanol (MCTE) & 0 & 0 & 0 & 0 \\
\hline Fish oil + dextrose $(F D)$ & 1.0 & 0 & 0 & 0 \\
\hline Fish oil + ethanol (FE) & $4.0 \pm 1.9 *$ & $3.6 \pm 1.4^{*}$ & $+{ }^{b}$ & + \\
\hline Female fish oil + dextrose (FFD) & $1.9 \pm 0.7 *$ & $2.2 * \pm 0.8$ & + & + \\
\hline Female fish oil + ethanol (FFE) & $7.0 \pm 1.9 *, * *$ & $8.1 \pm 2.2^{*, * *}$ & + & + \\
\hline
\end{tabular}

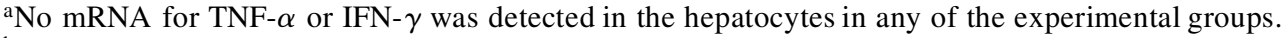

$\mathrm{b}_{+}$, faint band for mRNA seen.

$* p<0.01$ vs. MCTD, MCTE, FD.

$* * p<0.01$ vs. FFD.

MIF in liver, we also determined TNF- $\alpha$ and IFN- $\gamma$ mRNA in the different cell types. Our results show that TNF- $\alpha$ and IFN- $\gamma$ are also increased in the same groups that show increased MIF (FE, FFD, FFE) (Table 4). In contrast to the cellular expression of MIF that occurred in all three cell types, the increase in TNF- $\alpha$ and IFN- $\gamma$ was restricted mainly to Kupffer cells (Table 4).

\section{In situ hybridization and immunohistochemical analysis of $M I F$}

In situ hybridization confirmed the low level of MIF expression in the livers of rats without evidence of liver injury (Fig. 2). In animals showing the presence of necrosis and inflammation, there was a marked increase in MIF mRNA expression (Fig. 2). The increased expression of MIF in hepatocytes confirmed the results of RT-PCR analysis. Combined in situ hybridization and immunohistochemistryshowed that ED1positive Kupffer cells were the major source of MIF (data not shown).

In the animals showing necroinflammatory changes, the level of MIF protein, detected immunohistochemically, was higher from that seen in dextrose-fed animals. In fact, in some of the animals exhibiting liver injury, the immunostaining intensity was low despite the presence of necroinflammatory changes. Because of the known association between high levels of endotoxin and loss of MIF protein expression, we divided the rats in the FE groups into those with levels of endotoxin $<50 \mathrm{pg} / \mathrm{ml}$ and $>50 \mathrm{pg} / \mathrm{ml}$ at the time of killing. Of the 10 animals fed FE, 6 had a level of $>50 \mathrm{pg} / \mathrm{ml}$. The meaning staining intensity in the rats with endotoxin levels of $>50 \mathrm{pg} / \mathrm{ml}$ was $1.3(1.3 \pm 0.5)$ compared with $2.8(2.8 \pm 0.4)$ in rats with endotoxin levels $<50$ $\mathrm{pg} / \mathrm{ml}(p<0.05)$.

\section{DISCUSSION}

Over the past few years, MIF has emerged as a pivotal cytokine that plays an important role in the control of inflammatory processes. ${ }^{(10,27-30)} \mathrm{MIF}$, originally described as a T cell cytokine, was subsequently found to be produced by macrophages and monocytes in response to endotoxin. ${ }^{(10)}$ Once released, MIF induces the expression of other proinflammatory mediators, thereby promoting and amplifying the inflammatory response. ${ }^{(10)}$ The results of the present study indicate that upregulation of MIF occurs in association with inflammatory changes in the liver and coincides with increased levels of endotoxin and lipid peroxidation and upregulation of TNF- $\alpha$ and IFN- $\gamma$. Our hypothesis is that upregulation of MIF, TNF- $\alpha$, and IFN$\gamma$, which occurs in association with endotoxemia and lipid peroxidation, promotes necroinflammatory changes in alcoholic liver injury. TNF- $\alpha$ levels are increased in both experimental and human ALD ${ }^{(25,31)}$ and TNF- $\alpha$ contributes to inflammatory changes in the liver. ${ }^{(32)}$ An important function of IFN- $\gamma$ is modulation of cytokine production. ${ }^{(24)}$ IFN- $\gamma$ induces TNF- $\alpha$ synthesis and also production of other proinflammatory cytokines, such as interleukin-12.(33) The mechanism regulating TNF- $\alpha$, and IFN- $\gamma$ production in necroinflammatory liver injury, however, remains unclear. In vitro, MIF directly induces TNF- $\alpha$ and IFN- $\gamma$ production, ${ }^{(34)}$ demonstrating that MIF is a key molecule responsible for TNF- $\alpha$ and IFN- $\gamma$ production by macrophages. Unlike TNF- $\alpha$ and IFN- $\gamma$, which are inducible, MIF is preformed. It is very possible that MIF is rapidly released from the intracellular store of both Kupffer cells and hepatocytes after alcoholic stress. Once released, MIF acts as the first proinflammatory cytokine to induce TNF- $\alpha$ and IFN- $\gamma$ expression. Therefore, MIF may play a key pathogenic role in liver inflammation.

To examine MIF production by individual cell types, hepatocytes, endothelial cells, and Kupffer cells were isolated from rats in the different experimental groups. Increased expression of MIF was seen in all cell types in the livers of alcohol-fed rats showing evidence of pathologic liver injury (MFE and FFE). By in situ hybridization and immunostaining, Kupffer cells were shown to be the major MIF-producing cells, consistent with the functional role of this cell in the liver inflammatory response. MIF secreted by nonmacrophage-type cells, such as hepatocytes, can halt macrophage migration and promote macrophage accumulation in the vicinity of MIF-producing cells. It is noteworthy that increased levels of MIF production by hepatocytes correlated with inflammatory changes. The increased levels of MIF, TNF- $\alpha$, and IFN- $\gamma$ in the Kupffer cell are consistent with previous observations that describe a major role for the Kupffer cell in alcoholic liver injury. ${ }^{(5)}$ The Kupffer cell is the predominant immune and inflammatory effector cell in the liver and, in response to such stimuli as endotoxin 

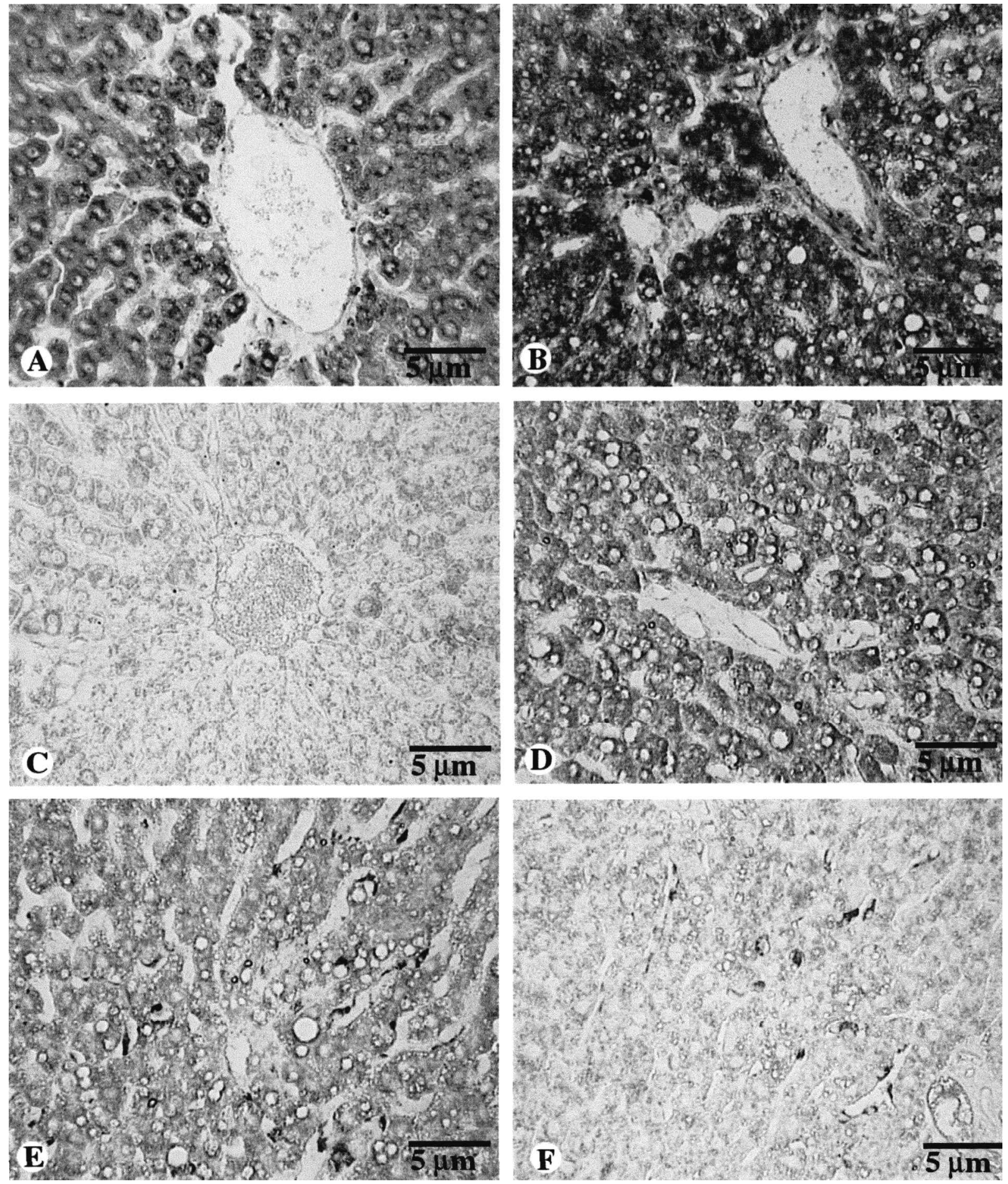

FIG. 2. MIF expression in the liver of rats fed ethanol and different dietary fats. In rats showing no evidence of liver injury, that is, rats fed MCTD, MCTE, and FD, a low level of MIF mRNA expression was seen in liver. (A) A representative section of liver from a rat fed MCTD is shown. (B) Rats fed FD showed increased MIF mRNA expression, with hepatocytes around the central vein showing the highest expression. Immunohistochemical analysis of rat liver shows low staining for MIF protein in rats fed MCTD, MCTE, and FD. (C) A representative section of liver from a rat fed MCTD is shown. (D) In rats fed FE, increased staining intensity was seen in the liver, especially in the centrilobular area. (E) In some of the rats fed FE, however, the staining intensity was decreased in hepatocytes but remained high in the Kupffer cells. (F) In a female rat fed FE, the staining intensity for MIF in hepatocytes was lower than that seen in (D and E) the male FE rat. The Kupffer cells, however, showed increased MIF staining. 
and lipid peroxidation, generates proinflammatory stimuli, such as cytokines and eicosanoids. MIF may also promote hepatic stellate cell proliferation by increasing production of such growth factors as platelet-derived growth factor. ${ }^{(35)}$ The direct link between MIF and secretion of growth factors by hepatic stellate cells remains to be established.

The increase in MIF mRNA without an accompanying increase in MIF protein suggests that MIF exists as a preformed protein in the liver and is rapidly released on stimulation. ${ }^{(10,27)}$ Resident macrophages in the liver respond to endotoxin by increasing the mRNA levels, although not that of MIF protein. In fact, MIF immunostaining in most tissues in endotoxintreated rats is weak, suggesting loss of MIF protein into the circulation. ${ }^{(10)}$ Our results show depleted levels of immunoreactive MIF protein and increased MIF mRNA in rats with the higher levels of endotoxin, suggesting release of preformed MIF into the circulation. These results are consistent with observations showing that an abrupt loss of MIF protein in liver occurs $6 \mathrm{~h}$ after endotoxin administration, and by $24 \mathrm{~h}$, immunoreactivity to MIF is restored. ${ }^{(10)}$ As a possible explanation for the variability of endotoxin-mediated loss of MIF immunoreactivity in our study, it is well known that in rats fed ethanol intragastrically, a cycling of endotoxin levels is observed.(9) Thus, the variability of endotoxin levels seen in the rats at death probably reflects the cycling of endotoxin in blood, and loss of MIF immunostaining in rats with the higher endotoxin levels is consistent with endotoxin-mediated release of preformed MIF.

Recent observations made in our laboratory also provide additional insights into the mechanism that may account for MIFmediated effects in alcoholic liver injury. MIF stimulates phospholipase $\mathrm{A}_{2}$ activity and arachidonic acid release, suggesting the possibility that the arachidonic acid-eicosanoid pathway is an important component of MIF-mediated effects. ${ }^{(36)}$ We have previously shown increased phospholipase and cyclooxygenase-2 activities in ethanol-fed rats exhibiting pathologic liver injury. ${ }^{(20)}$ In conjunction with previous studies in the intragastric feeding rat model for alcoholic liver injury, which show an increase in the levels of proinflammatory cytokines and eicosanoids, the results of the present study assign a critical role for MIF in the pathogenesis of alcoholic liver injury.

In conclusion, our results suggest that MIF is an important mediator of the inflammatory response in ALD. Given the central role of MIF in the immune response, MIF is an attractive therapeutic target in the treatment of inflammatory liver injury.

\section{ACKNOWLEDGMENTS}

This study was supported by grants from The University of Hong Kong, Hong Kong Research Grants Council, Cheng Si Yuan (China International) Hepatitis Research Foundation and National Institute of Health.

\section{REFERENCES}

1. NANJI, A.A., and ZAKIM, D. (1996). Alcoholic liver disease. In: Hepatology: A Textbook of Liver Disease, 3rd ed. D. Zakim and T.D. Boyer (eds.) Philadelphia: W.B. Saunders, pp. 891-961.

2. FUKUI, H., BRAUNER, B., BODE, J.C., and BODY, C. (1991).
Plasma endotoxin concentrations in patients with alcoholic and non-alcoholic liver disease: re-evaluation with an improved chromogenic assay. Hepatology 12, 162-169.

3. NANJI, A.A., KHETTRY, U., SADRZADEH, S.M.H., and YAMANDAKA, T. (1993). Severity of liver injury in experimental alcoholic liver disease. Correlation with plasma endotoxin, prostaglandin $\mathrm{E}_{2}$, leukotriene $\mathrm{B}_{4}$, and thromboxane $\mathrm{B}_{2}$. Am. J. Pathol. 142, 367-373.

4. POLAVARAPU, R., SPITZ, D.R., SIM, J.E., FOLLANSBEE, M.H., OBERLEE, L.W., RAHEMTULLA, A., and NANJI, A.A. (1998). Increased lipid peroxidation and impaired antioxidant enzyme function is associated with pathological liver injury in experimental alcoholic liver disease in rats fed diets high in corn oil and fish oil. Hepatology 27, 1317-1323.

5. THURMAN, R.G. (1998). Mechanisms of hepatic toxicity II. Alcoholic liver injury involves activation of Kupffer cells by endotoxin. Am. J. Physiol. 275, G605-G611.

6. ADACHI, Y., MOORE, L.E., BRADFORD, B.U., GAO, W., and THURMAN, R.G. (1995). Antibiotics prevent liver injury in rats following long-term exposure to ethanol. Gastroenterology 108, 218-224.

7. BAEUERLE, P.A., and BALTIMORE, D. (1996). NF-kappa B: ten years after. Cell 87, 13-20.

8. BARNES, P.J., and KARIN, M. (1997). Nuclear factor-kappaB: a pivotal transcription factor in chronic inflammatory diseases. N. Engl. J. Med. 336, 1066-1071.

9. LI, J., NGUYEN, V., FRENCH, B.A., PARLO, W.A.F., SU, G.L., FU, P., YUAN, Q.X., and FRENCH, S.W. (2000). Mechanism of alcohol cyclic pattern: role of the hypothalamic-pituitary-thyroid axis. Am. J. Physiol. 279, G118-G125.

10. BACHER, M., MEINHARDT, A., LAN, H.Y., MU, W., METZ, C.N., CHESNEY, J.A., CALANDRA, T., GEMSA, D., DONELLY, T., ATKINS, R.C., and BUCALA, R. (1997). Migration inhibitory factor expression in experimentally induced endotoxemia. Am. J. Pathol. 150, 235-246.

11. BACHER, M., METZ, C.N., CALANDRA, T., MAYER, K., CHESNEY, J., LOHOFF, M., GEMSA, D., DONNELLY, T., and BUCALA, R. (1996). An essential regulatory role for macrophage migration inhibitory factor in T-cell activation. Proc. Natl. Acad. Sci. USA 56, 7849-7854.

12. NATHAN, C.F., KARNOVSKY, M.L., and DAVID, J.R. (1971). Alterations of macrophage functions by mediators from lymphocytes. J. Exp. Med. 133, 1356-1376.

13. FRENCH, S.W., MIYAMOTA, K., and TSUKAMOTO, H., (1986). Ethanol-induced fibrosis in the rat: role of the amount of dietary fat. Alcohol Clin. Exp. Res. 10, 13S-19S.

14. TSUKAMOTO, H., GAAL, K., and FRENCH, S.W. (1990). Insight into the pathogenesis of alcoholic liver necrosis and fibrosis: status report. Hepatology 12, 599-608.

15. NANJI, A.A., and FRENCH, S.W. (1989). Dietary linoleic acid is required for development of experimentally induced alcoholic liver injury. Life Sci. 44, 223-237.

16. NANJI, A.A., MENDENHALL, C.L., and FRENCH, S.W. (1989). Beef fat prevents alcoholic liver disease in the rat. Alcohol Clin. Exp. Res. 13, 15-19.

17. IIMURO, Y., FRANKENBERG, M.V., ARTEEL, G.E., BRADFORD, B.U., WALL, C.A., and THURMAN, R.G. (1997). Female rats exhibit greater susceptibility to early alcohol-induced liver injury than males. Am. J. Physiol. 272, G1186-G1194.

18. TOTH, C.A., THOMAS, P., BROITMAN, S.A., and ZAMCHEK, N. (1985). Receptor-mediated endocytosis of carcinoembryonic antigen by rat liver Kupffer cells. Cancer Res. 45, 392-397.

19. SEGLEN, P. (1973). Preparation of rat liver cells. III. Enzymatic requirements for tissue dispersion. Exp. Cell Res. 82, 391-398.

20. NANJI, A.A., MIAO, L., THOMAS, P., RAHEMTULLA, A., KHWAJA, S., ZHAO, S., PETERS, D., TAHAN, S.R., and DAN- 
NENBERG, A.J. (1997). Enhanced cyclooxygenase-2 gene expression in alcoholic liver disease in the rat. Gastroenterology 112, 943-951.

21. ALPINI, G., PHILLIPS, J.O., VROMAN, B., and LARUSSO, N.F. (1994). Recent advances in the isolation of liver cells. Hepatology 20, 494-514.

22. RIVERA, C.A., and THURMAN, R.G. (1998). Tips for measuring endotoxin in plasma. Alcohol Clin. Exp. Res. 22, 2192-2194.

23. CHOMCZYNSKI, P., and SACCHI, N. (1997). Single-step method for RNA isolation by acid guanidinium thiocyanate-phenol-chloroform extraction. Anal. Biochem. 162, 156-159.

24. NANJI, A.A., JOKELAINEN, K., RAHEMTULLA, A., MIAO, L., FOGT, F., MATSUMOTO, H., TAHAN, S.R., and SU, G.L. (1999). Activation of nuclear factor kappa B and cytokine imbalance in experimental alcoholic liver disease in the rat. Hepatology 30, 934-943.

25. NANJI, A.A., ZHAO, S., SADRZADEH, S.M.H., and WAXMAN, D.J. (1994). Use of reverse transcription PCR to evaluate in vivo cytokine gene expression in rats fed ethanol for long periods of time. Hepatology 19, 1483-1487.

26. NISHIHIRA, J., KURIYAMA, T., SAKAI, M., NISHI, S., OHKI, S., and HIKICHI, K. (1995). The structure and physiochemical properties of rat liver macrophage migration inhibitory factor. Biochim. Biophys. Acta 1247, 159-162.

27. LAN, H.Y., BACHER, M., and YANG, N. (1997). The pathogenic role of macrophage migration inhibitory factor in immunologically induced kidney disease in the rat. J. Exp. Med. 185 1455-1465.

28. LAN, H.Y., YANG, N., NIKOLIC-PASTERSON, D.J., YU, X.Q., MU, W., ISBEL, N.M., METZ, C.N., BUCALA, R., and ATKINS, R.C. (2000). Expression of macrophage migration inhibitory factor in human glomerulonephritis. Kidney Int. 57, 499-509.

29. KOBAYASHI, S., NIHIHIRA, J., WATANABE, S., and TODO, S. (1999). Prevention of lethal acute hepatic failure by antimacrophage migration inhibitory factor antibody in mice treated with bacille Calmette-Guérin and lipopolysaccharide. Hepatology 29, 1752-1759.

30. TESCH, G.H., NIKOLIC-PATERSON, D.J., METZ, C.N., MU, W., BACHER, M., BUCALA, R., ATKINS, R.C., and LAN, H.Y.
(1998). Rat mesangial cells express macrophage migration inhibitory factor in vitro and in vivo. J. Am. Soc. Nephrol. 9, 417-424.

31. McClAIN, C.J., BARVE, S., DEACIUC, I., KUGELMAS, M., and HILL, D. (1999). Cytokines in alcoholic liver disease. Semin. Liver Dis. 19, 205-219.

32. BRADHAM, C.A., PLUMPE, J., MANNS, M.P., BRENNER, D.A., and TRAUTWEIN, C. (1998). Mechanisms of hepatic toxicity: I. TNF-induced liver injury. Am. J. Physiol. 275, G387-G392.

33. BRUNDA, M.J. (1994). Interleukin 12. J. Leukocyte Biol. 55, 280-287.

34. CALANDRA, T., BERNHAGEN, J., MITCHELL, R.A., and BUCALA, R. (1994). The macrophage is an important and previously unrecognized source of macrophage migration inhibitory factor. J. Exp. Med. 179, 1895-1994.

35. CALANDRA, T.T., ECHTENACHAR, B., ROY, D.L., PUGIN, J., METZ, C.N., HULTNER, L.L., HEUMANN, D., MANNEL, D., BUCALA, R., and GLAUSER, M.P. (2000). Protection from septic shock by neutralization of macrophage migration inhibitory factor. Nat. Med. 6, 164-170.

36. MITCHELL, R.A., METZ, C.N., PENG, T., and BACALA, R. (1999). Sustained mitogen-activated protein kinase (MAPK) and cytoplasmic phospholipase $\mathrm{A}_{2}$ activation by macrophage migration inhibitory factor (MIF). J. Biol. Chem. 274, 18100-18106.

Address reprint requests to: Dr. Amin A. Nanji

Clinical Biochemistry Unit

LG 136, Block K

Queen Mary Hospital 102 Pokfulam Road

Hong Kong

Tel: (852) 2855-3201

Fax: (852) 2855-9915

E-mail: ananji@pathology.hku.hk

Received 14 June 2001/Accepted 7 August 2001 